\title{
Ethical Leadership, Employees Commitment and Organizational Effectiveness: A Study of Non-Faculty Members
}

\author{
By Abayomi Olarewaju Adeoye*
}

\begin{abstract}
The expansion, growth and maintaining competitiveness is a function of good and effective leadership in place coupled with the commitment on the part of both the employees' and the firm itself that will determine the organization effectiveness. The thrust of this article is to scrutinize the impact of ethical leadership and employees' commitment on organizational effectiveness in an academic set-up by focusing on non-faculty members. The research design adopted was descriptive survey and 200 questionnaires were administered out of which 181 (90.5\%) were found usable for the study. Three hypotheses were tested and the result revealed that there is a relationship between ethical leadership and organizational effectiveness. It was found out that ethical leadership influences employees' commitment and attitude to work. It was equally established that there is significant relationship between ethical leadership, employees' commitment and organizational effectiveness. It is concluded that ethical leadership is a propeller that will drive employees' commitment and enhance organizational effectiveness in a university environment. The study therefore recommended amidst others that university management should attempt to embrace ethical leadership as an indicator which will help in improving the quality of service and increase employees' sense of commitment. Ethical leadership should be given a paramount consideration in the institution in other to improve employees' commitment in order to achieve organizational effectiveness. (JEL L29, J5, I2)
\end{abstract}

Keywords: Employees Commitment, Ethical Leadership, Non-Faculty Members, Organizational Effectiveness.

\section{Introduction}

There is threat to global business growth despite the fact that economies are growing, becoming more difficult and complex, and it is more demanding than before. Leaders who are supposed to be managers within firms are expected to be consistently responsible in ensuring that employees are committed in the right way to ensure organizational effectiveness (Mentari, 2015; Obicci, 2015). Leadership was viewed as the procedure to influence both leaders and followership to accomplish the goals and objectives of an organization through changes (Caldwell, Hayes \& Long, 2010; Lussier \& Achua, 2004:5). In the $21^{\text {st }}$ century, there is an assets that occupies a big portion in organizational perspective and this asset is the most valued thing to any organization. These are the employees or what is referred

*Associate Professor, Lagos State University, Nigeria. 
to as human capital (Khuong \& Nhu, 2015; Scullion, Collings \& Gunnigle, 2007). Employees that are loyal, dedicated and committed have the tendency to record greater performance and put-in significant part of their time to enhance organizational outcome (Khuong \& Nhu, 2013).

Employees' commitment describes the degree of loyalty of a worker to the organization which incorporate leads to the employee's intention and willingness to work or engaged in the organizational activities in order to accomplish the goals and aspirations of the organization (Bateman \& Strasser, 1984; Sharma \& Bajpai, 2010). Employee's organizational commitment is viewed as employee's affiliation and integration with organization as well as emotional attachment to ensure the achievement of the organizational objectives and the extent the employee desires to stay with the organization by giving thought to the realization of the objectives of the organization (Buchanan, 1974; Marthis \& Jackson, 2000; Ahmad, Iqbal, Javed \& Hamad, 2014). Employees' organizational commitment is also described as "the relative strength of an individual's identification with and involvements in a particular organization" (Mowday, Porter \& Steers, 1982:27, Steyrer, Schiffinger \& Lang, 2008). In the views of Kim and Brymer (2011), employees commitment means "employees" advanced stages of exertion and connection to basic levels of active and economic routine of the organizational. O'Reilly and Chatman (1986) cited in Caldwell (1990) defined organizational commitment as the basis of an individual or employee's attachment to the organization psychologically while Kelman (1958) opined that commitment to an organizational is a function of three different foundation of attachment namely compliance, identification and internalization. From the extant literature, organizational effectiveness has been alluded as a way of infusing the importance of culture through inspiring and exploiting the relevance of its resources which the life pattern of each organization in achieving effectiveness is entrenched and through the norms that has influenced every participant in the organization (Schein, 2010). In order for organizational effectiveness to be attained, organizational managers and leaders are strongly motivated to adopt the trait aspect of their employees to ascertain their commitment to their jobs (Meyer, Stanley, Herscovitch \& Topolnytsky, 2002).

\section{Literature Review}

Ethical leadership plays a cultural effect on social relationship which create a friendly environment for employees to work with full motivation for quality production, Khuong and Nhu (2015) also agreed, in their investigation that properties of ethical management and organizational values on employee's affability assist organizational pledge in travel sector. Similar study was carried out by Obicci (2015) who explored the possessions of ethical leadership scheduled with employee performance in the civic segment in Uganda, results of the study disclose that employee commitment is importantly inclined by ethical leadership. Leadership is a dynamic reserved for making and nourishing organization, publics and humanities. It includes founding a pure image, distribution of the vision with assistants so that they can donate their own share in realizing organizational aims 
and purposes. Ethical problem is a global phenomenon and it is a vital issue in corporate organizations; and corporate front-runners must take active measures in ensuring ideal ethical leadership practices. Ethical leadership remain professed by way of consuming a wide ethical alertness and distress for wholly patrons which comprises of employees.

\section{Ethical Leadership}

Leadership is of paramount importance when it comes to the study of employee commitment and organizational effectiveness, however leadership has been widely defined as the process of influencing a team of individuals to accomplish the organizational objectives and common goals through change (Northouse, 2007, Caldwell et al, 2010; Kaiser, Hogan \& Craig, 2008; Bello, 2012). Merger of leadership and ethical leadership stands as one of the crucial demands for any organization to remain competitive, hence it is clearly defined by Brown, Travino plus Harrison (2005:120) as the "demonstration of normatively appropriate conduct through personal actions and interpersonal relationships, and the promotion of such conduct to followers through two-way communication reinforcement and decision makings". It is advised that ethical leadership behaviours plays a vital role in pushing and enhancing employee attitude and behaviours which has a linkage to the commitment level, job satisfaction, motivation and turnover intentions of employees (Brown et al, 2005; Walumbwa, Mayer, Wang, Workman \& Christensen, 2011; Heirbach, Mignonac, Vanden Berghe \& Negrini, 2009; Menlari, 2015; Kim \& Brymer, 2011; Khuong \& Nhu, 2015). However, Freeman and Stewart (2006) concur that ethical leader possess the "right values" and "strong character" that gives a sense of direction to groups within the organization and withstand temptations.

Khuong and Nhu (2015) in their study alluded that ethical leadership is significantly related to effective trust, negatively related to abusive supervision and no similarity demographically between leader and followers. It is however, concluded that ethical leaders were truthful, trustworthiness, fair in making decisions, respect, integrity, honesty, equity, justice, compassionate and good at disseminating information with their subordinates (Bello, 2012; Khuong \& Nhu, 2015).

$\mathrm{H}_{1}$ : There exist a positive link between ethical leadership and organizational effectiveness.

\section{Employee's Commitment}

Literature has availed that employee's commitment also stands for organizational commitment connecting workers dedication and support to the organization (Khuong \& Nhu, 2015; Bateman \& Strasser, 1984). This has been identified as one of the cogent factors in employee's encouragement and outcome within the organization (Tolentino, 2013; Ismail \& David, 2014). Commitment is viewed as integrating oneself into the goals, objectives and core ideals of the 
organization, readiness to apply energy, and effort for the sake of the organization with an innate opinion of his organizational membership within the organization which also means it is the focus and belief of an employee or individual attachment to a particular task or his job (Ramay and Ramay 2012, Ismail and David 2014, Tolentino 2013, Mowday et al. 1979). It has also been contended that commitment denotes the aspiration of an employee to share the beliefs and aims of the organization besides working towards attainment and achievement of organizational success amidst rivals (Becker et al. 1996, Sharma and Bajpai, 2010, Pandy et al. 2019).

Research on commitment was dominated by the model of commitment developed by Meyer and Allen (1991) as cited by (Meyer et al. 2002, Khuong and $\mathrm{Nhu}, 2015)$. Three major components of organizational commitment were stressed by Meyer and Allen (1991) and these three constructs is made up of affective level, continuity level and normative levels which are more discussed as components, dimensions or factors of organizational commitment (Ismail and David 2014, Khuong and Nhu 2015, Meyer and Allen 1991). The three dimensions of organizational commitment were expatiated upon as follows. First, the affective level points to workers emotional attachment to, affiliation to and engagement in the organization. Second, the continuity level means commitment anchored on the costs of employees having an intent of leaving the organization. Lastly, the normative level refers to employees having the feelings of obligationary support to stay with the organization. This is supported by the work of Cheah, Chong, Yeo and Pee (2016).

$\mathrm{H}_{\mathrm{ii}}$ : There exist a significant influence between ethical leadership and employee commitment.

\section{Organizational Effectiveness}

The extant literature in recent times placed more concentration on the determinants of organizational effectiveness such as culture, product development and innovation (Liu et al. 2010, Lucas et al. 2013, Büschgens et al. 2013, Scineider et al. 2013, Slater et al. 2014). Mahadeen et al. (2016) found a positive impact of internal control system on organisational effectiveness. Heilman and Philips (2011) alluded that organizational effectiveness is an important apparatus to validate progress made in mission fulfilment and goal accomplishment. They opined that in order to achieve better organizational effectiveness, management should give priority to communication, interaction, leadership, direction, adaptability and positive cum conducive environment. Bartuševičienè and Šalcalylè (2013) submitted that organizational effectiveness is adopted to determine the performance of an organization which correlated to the attainment of organizational mission, goals and vision.

$\mathrm{H}_{\mathrm{iii}}$ : There is a correlational relationship between ethical leadership, employee's commitment and organizational effectiveness. 


\section{Research Method}

Investigation study design was adopted in this study. Primary and secondary data were used to gather information for inference. The target population covers Non-Academic Staff of Lagos State University. The motivation for choosing nonacademic staff is because they constitute the administrative cadre of the University which determines the effectiveness of the university as an organization. Purposive sampling technique (non-probabilistic sampling technique) was used to choose the section from the populace. Out of the total population, 200 respondents remained chosen for the model size through the use of simple random sampling technique. A structured four Likert scale questionnaire (self-developed) was design to elicit information from the respondents. Content validity was adopted to ascertain the strength of the instrument designed for this study while the Cronbach's alpha of 0.76 showed the reliability of the questionnaire. Out of the 200 questionnaires administered 181 were found valid and used for the analysis. The revision used descriptive and inferential statistics to test the hypotheses.

\section{Results and Discussion}

Table 1. Descriptive Statistics of Respondents' Demographic Information

\begin{tabular}{|l|c|c|}
\hline Alternatives & Frequency & Percentage (\%) \\
\hline Gender & 118 & $65.20 \%$ \\
\hline Male & 63 & $34.80 \%$ \\
\hline Female & & \\
\hline Age & 16 & $8.80 \%$ \\
\hline $21-30$ years & 48 & $26.50 \%$ \\
\hline $31-40$ years & 83 & $45.90 \%$ \\
\hline $41-50$ years & 34 & $17.80 \%$ \\
\hline Above 50 years & & \\
\hline Highest Qualification & 31 & $17.10 \%$ \\
\hline OND/NCE & 92 & $50.80 \%$ \\
\hline HND/BSC/(Ed.) & 47 & $26 \%$ \\
\hline M.Ed./M.Sc./MA & 11 & $6.10 \%$ \\
\hline PhD & \multicolumn{2}{|}{} \\
\hline Length of Service & 46 & $25.40 \%$ \\
\hline Less than 5yrs & 111 & $61.30 \%$ \\
\hline $5-10 y r s$ & 17 & $9.40 \%$ \\
\hline $11-15 y r s$ & 7 & $3.90 \%$ \\
\hline Above $15 y r s$ & & \\
\hline Source fied & & \\
\hline
\end{tabular}

Source: field survey, 2019 
Table 2. Analysis of Responses

\begin{tabular}{|c|c|c|c|c|c|}
\hline $\mathrm{S} / \mathrm{N}$ & Ethical Leadership & $\begin{array}{l}\text { Strongly } \\
\text { Agree } \\
\text { (4) }\end{array}$ & $\begin{array}{c}\text { Agree } \\
\text { (3) }\end{array}$ & $\begin{array}{c}\text { Disagree } \\
\text { (2) }\end{array}$ & $\begin{array}{l}\text { Strongly } \\
\text { Disagree } \\
\text { (1) }\end{array}$ \\
\hline 1 & $\begin{array}{l}\text { Do listen to what employees } \\
\text { have to say. }\end{array}$ & $124(68.6 \%)$ & $50(27.6 \%)$ & $7(3.9 \%)$ & - \\
\hline 2 & $\begin{array}{l}\text { Discipline employees who } \\
\text { violate ethical standard. }\end{array}$ & $78(43.1 \%)$ & $83(45.9 \%)$ & $19(10.5 \%)$ & $1(0.6 \%)$ \\
\hline 3 & $\begin{array}{l}\text { Has the best interest of } \\
\text { employee in mind }\end{array}$ & $89(49.2 \%)$ & $71(39.2 \%)$ & $21(11.6 \%)$ & - \\
\hline 4 & $\begin{array}{l}\text { Site an example of how to } \\
\text { do things the right way in } \\
\text { terms of ethics. }\end{array}$ & $80(44.2 \%)$ & $84(46.4 \%)$ & $16(8.8 \%)$ & $1(0.6 \%)$ \\
\hline 5 & $\begin{array}{l}\text { Discuss business ethics or } \\
\text { values with employees }\end{array}$ & $92(50.8 \%)$ & $70(38.7 \%)$ & $18(9.9 \%$ & $1(0.6 \%)$ \\
\hline & Employee Commitment & & & & \\
\hline 6 & $\begin{array}{l}\text { I would be very glad to } \\
\text { apply the rest of my } \\
\text { profession in this } \\
\text { organization. }\end{array}$ & $85(47 \%)$ & $75(41.4 \%)$ & $19(10.5 \%)$ & $2(1.1 \%)$ \\
\hline 7 & $\begin{array}{l}\text { I do not feel like slice of my } \\
\text { family at this organization. }\end{array}$ & $16(8.8 \%)$ & $3(1.7 \%)$ & $75(41.4 \%)$ & $87(48.1 \%)$ \\
\hline 8 & $\begin{array}{l}\text { I do not sense warmly } \\
\text { devoted to this organization. }\end{array}$ & $11(6.1 \%)$ & $5(2.8 \%)$ & $80(44.2 \%)$ & $85(47 \%)$ \\
\hline 9 & $\begin{array}{l}\text { Right now, staying with my } \\
\text { job at this organization is a } \\
\text { matter of necessity as much } \\
\text { as I need }\end{array}$ & $91(50.3 \%)$ & $67(37 \%)$ & $18(9.9 \%)$ & $5(2.8 \%)$ \\
\hline 10 & $\begin{array}{l}\text { I would not leave my } \\
\text { organization right now } \\
\text { because of my sense of } \\
\text { obligation to it. }\end{array}$ & $96(53 \%)$ & $51(28.2 \%)$ & $29(16 \%)$ & $5(2.8 \%)$ \\
\hline & $\begin{array}{l}\text { Organizational } \\
\text { Effectiveness }\end{array}$ & & & & \\
\hline 11 & $\begin{array}{l}\text { Management has a } \\
\text { reasonable assurance that the } \\
\text { structure will support } \\
\text { planned goals and ideas. }\end{array}$ & $93(51.4 \%)$ & $74(40.9 \%)$ & $13(7.2 \%)$ & $1(0.6 \%)$ \\
\hline 12 & $\begin{array}{l}\text { My organization is fruitful in } \\
\text { realizing its objectives. }\end{array}$ & $94(51.9 \%)$ & $65(35.9 \%)$ & $14(7.7 \%)$ & $8(4.4 \%)$ \\
\hline 13 & $\begin{array}{l}\text { My organization ensures its } \\
\text { staff adherence to laws, } \\
\text { regulations and contract. }\end{array}$ & $96(53 \%)$ & $63(34.8 \%)$ & $18(9.9 \%)$ & $4(2.2 \%)$ \\
\hline 14 & $\begin{array}{l}\text { Management directives and } \\
\text { decisions rely on a timely } \\
\text { financial and managerial } \\
\text { reporting system. }\end{array}$ & $99(54.7 \%)$ & $60(33.1 \%)$ & $15(8.3 \%)$ & $5(2.8 \%)$ \\
\hline 15 & $\begin{array}{l}\text { My organization is gifted of } \\
\text { drawing the desirable } \\
\text { resources to yield its } \\
\text { product/ amenities. }\end{array}$ & $89(49.2 \%)$ & $45(24.9 \%)$ & $31(17.1 \%)$ & $16(8.8 \%)$ \\
\hline
\end{tabular}

Source: The Researcher, (2019). 
Table 1 revealed that $118(65.2 \%)$ are male while $63(34.8 \%)$ are female. This implies that there are more male than female respondents. $16(8.8 \%)$ are between 21-30 years, $48(26.5 \%)$ are between $31-40$ years, $83(45.9 \%)$ are between $41-50$ years and $34(17.8 \%)$ are 50 years and above which revealed that majority of the respondents are between 41-50 years.

$31(17.1 \%)$ of the respondents had Ordinary National Diploma/National Certificate of Education (OND/NCE) as their educational qualification, 92 (50.8\%) had Higher National Diploma/Bachelor of Science/Bachelor Of Education (HND/BSC/(ED)) as their educational qualification, $47(26 \%)$ had Masters of Education/Masters of Science/Masters of Art (M.ED/M.SC/MA) as their educational qualification and $11(6.1 \%)$ had $\mathrm{PhD}$ as their educational qualification which revealed that majority of the respondents had HND/BSC/(ED) as their highest educational qualification. $46(25.4 \%)$ of the respondents spent less than five years in service, $111(61.3 \%)$ are between 5-10 years in service, 17 (9.4\%) are between 11-15 years in service and the remaining 7 (3.9\%) had spent above 15 years in service which revealed that majority of the respondents had spent between 5-10 years in service.

Table 2 shows that high percentage of the respondents agreed to the statements on ethical leadership, employee commitment and organizational effectiveness.

\section{Test of Hypotheses}

Hypothesis One: There exist a positive link between ethical leadership and organizational effectiveness.

The result above (Table 3 ) indicate the bond between ethical leadership and organizational effectiveness $(r=0.910, p$-value $<0.000)$. This relationship is significant because the generated p-value $(0.000)$ is less than the close of significant (0.050) used for the revision.

Table 3. Ethical Leadership and Organizational Effectiveness

\begin{tabular}{|c|c|c|c|}
\hline \multicolumn{4}{|c|}{ Correlations } \\
\hline & & $\begin{array}{c}\text { Ethical } \\
\text { Leadership }\end{array}$ & $\begin{array}{l}\text { Organizational } \\
\text { Effectiveness }\end{array}$ \\
\hline \multirow{3}{*}{ Ethical Leadership } & Pearson Correlation & 1 & $.910^{* *}$ \\
\hline & Sig. (2-tailed) & & .000 \\
\hline & $\mathrm{N}$ & 181 & 181 \\
\hline \multirow{3}{*}{$\begin{array}{l}\text { Organizational } \\
\text { Effectiveness }\end{array}$} & Pearson Correlation & $.910^{* * *}$ & 1 \\
\hline & Sig. (2-tailed) & .000 & \\
\hline & $\mathrm{N}$ & 181 & 181 \\
\hline
\end{tabular}

This result cannot reject the hypothesis that there exists a significant positive link between ethical leadership and organizational effectiveness among non-Academic staff of Lagos State University. 
It is evident from the results that ethical leadership has a significant link with organizational effectiveness. This reveals that a leader with good ethical leadership skills will boost organizational effectiveness.

Hypothesis Two: There exist a significant influence between ethical leadership and employee commitment.

The model summary shows that ethical leadership influences employee commitment (Table 4). The coefficient of determination $\left(\mathrm{R}^{2}=0.762\right)$ shows that $76.2 \%$ of the achievement noted in employee commitment is contributed by ethical leadership. This outcome is statistically significant because the p-value of the result $(0.000)$ is less than 0.05 level of significance used for the study. This indicates that ethical leadership significantly influences employee commitment.

The model signifies that a unit changes in ethical leadership rises employee commitment by the amount of 1.047. Therefore, the null hypothesis was accepted while alternative hypothesis was rejected.

Table 4. Ethical Leadership and Employee Commitment

\begin{tabular}{|c|c|c|c|c|c|c|c|c|}
\hline \multicolumn{8}{|c|}{ Model Summary } & \multirow[b]{2}{*}{ Sig. } \\
\hline \multicolumn{2}{|c|}{ Model } & $\mathrm{R}$ & $\begin{array}{c}\mathrm{R} \\
\text { Squar }\end{array}$ & \multicolumn{2}{|c|}{$\begin{array}{l}\text { Adjusted R } \\
\text { Square }\end{array}$} & \multicolumn{2}{|c|}{$\begin{array}{l}\text { Std. Error of the } \\
\text { Estimate }\end{array}$} & \\
\hline & 1 & $.873^{\mathrm{a}}$ & .762 & \multicolumn{2}{|c|}{.760} & \multicolumn{2}{|c|}{.29630} & $.000^{\mathrm{b}}$ \\
\hline \multicolumn{8}{|c|}{ a. Predictors: (Constant), ETHICAL LEADERSHIP } & \\
\hline \multicolumn{9}{|c|}{ Coefficients } \\
\hline \multirow{2}{*}{\multicolumn{3}{|c|}{ Model }} & $\begin{array}{r}\text { Unstal } \\
\text { Coet }\end{array}$ & $\begin{array}{l}\text { Irdized } \\
\text { ients }\end{array}$ & Stanc & Coefficients & \multirow{2}{*}{$\mathrm{t}$} & \multirow{2}{*}{ Sig. } \\
\hline & & & B & $\begin{array}{c}\text { Std. } \\
\text { Error }\end{array}$ & & eta & & \\
\hline \multirow[b]{2}{*}{1} & & ant) & -.173 & .190 & & & -.914 & .362 \\
\hline & $\begin{array}{r}\text { Et } \\
\text { LEA }\end{array}$ & AL & 1.047 & .044 & & 373 & 23.912 & .000 \\
\hline
\end{tabular}

Hypothesis Three: There is a correlational relationship between ethical leadership, employee commitment and organizational effectiveness.

The result in Table 5 reveals the relationship between ethical leadership, employee commitment and organizational effectiveness $(\mathrm{r}=0.873$, $\mathrm{p}$-value < 0.000 and $r=0.910, p$-value $<0.000),(, r=0.873$, $p$-value $<0.000$ and $r=0.946$, $\mathrm{p}$-value $<0.000)$ and $(\mathrm{r}=0.910, \mathrm{p}$-value $<0.000$ and 0.946 , $\mathrm{p}$-value $<0.000)$ respectively. This relationship is significant because the generated p-value $(0.000)$ is less than the level of significant (0.050) used for the study. This result denotes that there exists a significant correlational relationship between ethical leadership, employee commitment and organizational effectiveness among non-Academic staff of Lagos State University.

The relationship between ethical leadership, employee commitment and organizational effectiveness is significant at a high percentage. However, the relationship between employee commitment and organizational effectiveness has the highest percentage. It can be deduced that with good ethical leadership employee will be more committed ad this will enhance organizational effectiveness. 
Table 5. Ethical Leadership, Employee Commitment and Organizational Effectiveness

\begin{tabular}{|c|c|c|c|c|}
\hline \multicolumn{5}{|c|}{ Correlations } \\
\hline & & $\begin{array}{c}\text { Ethical } \\
\text { Leadership }\end{array}$ & $\begin{array}{c}\text { Employee } \\
\text { Commitment }\end{array}$ & $\begin{array}{l}\text { Organizational } \\
\text { Effectiveness }\end{array}$ \\
\hline \multirow{3}{*}{ Ethical Leadership } & $\begin{array}{c}\text { Pearson } \\
\text { Correlation }\end{array}$ & 1 & $.873^{* *}$ & $.910^{* *}$ \\
\hline & Sig. (2-tailed) & & .000 & .000 \\
\hline & $\mathrm{N}$ & 181 & 181 & 181 \\
\hline \multirow{3}{*}{$\begin{array}{l}\text { Employee } \\
\text { Commitment }\end{array}$} & $\begin{array}{c}\text { Pearson } \\
\text { Correlation }\end{array}$ & $.873^{* *}$ & 1 & $.946^{* *}$ \\
\hline & Sig. (2-tailed) & .000 & & .000 \\
\hline & $\mathrm{N}$ & 181 & 181 & 181 \\
\hline \multirow{3}{*}{$\begin{array}{l}\text { Organizational } \\
\text { Effectiveness }\end{array}$} & $\begin{array}{c}\text { Pearson } \\
\text { Correlation }\end{array}$ & $.910^{* *}$ & $.946^{* *}$ & 1 \\
\hline & Sig. (2-tailed) & .000 & .000 & \\
\hline & $\mathrm{N}$ & 181 & 181 & 181 \\
\hline
\end{tabular}

Form the results generated above, it is revealed that majority of the respondents agreed to the statements on ethical leadership, employee commitment and organizational effectiveness. The findings revealed that there is a positive and significant relationship among the three variables under study.

\section{Conclusion and Recommendations}

The study examines the relationship between ethical leadership, employee commitment and organizational effectiveness. Leadership stands as an energetic source aimed at forming and satisfying organization, societies and cultures. Ethical issue remains a global phenomenon that needs to be addressed. Ethical leaders exist, partakes in a wide-range of ethical responsiveness. In addition, it is an apprehension for all stakeholders including employees. Thus, leaders' obligation is to generate an ethically welcoming labour environment for all employees, interconnect ethical subjects, aid as role reproductions and in addition set instrument domicile for the advancement of accountable employees.

The results revealed in the study that there exist a positive and significant relationship between the three variables which is in tandem with the findings of (Bello 2012, Buschgens et al. 2013, Pandey et al. 2019). It is therefore anticipated that leaders who demonstrate ethical conduct would be expected to reflect the wants of employees and luxury for them justly. Without a doubt, each employee needs exertion for an actually and answerable employer and as such, leaders have to discharge their requirements on ethical issues and rise up to these expectations. It can be concluded that appropriate ethical leadership contributes to employee commitment as well as boosting organizational effectiveness. It was therefore recommended that: 
- Leaders ought to be qualified as modification agents, also act as a role replica, to generate an optimistic inspiration for their employees to additional boost their pledge to recital and remain with the organization.

- University management should attempt to accept equivalent conduct as ethical leadership pointer by way of helps for quality and increase employees' intelligence of obligation.

- Ethical leadership should be paramount in the institution so as to enhance employee commitment as well as organizational effectiveness.

\section{References}

Ahmad N, Iqbal N, Javed K, Hamad N (2014). Impact of organizational commitment and employee performance on the employee satisfaction. International Journal of Learning, Teaching and Educational Research, 1(1): 84-92.

Bartuševičienė I, Šalcalylė E (2013). Organizational Assessment: Effectiveness vs. Efficiency. Social Transformations in Contemporary Society, 1: 45-53.

Bateman TS, Strasser S (1984). A Longitudinal Analysis of the Antecedents of Organizational Commitment. Academy of Management Journal, 27(1): 95 - 112.

Becker TE, Billings RS, Eveleth DM, Gilbert NL (1996). Foci and Bases of Employee Commitment: Implications for Job Performance. Academy of Management Journal, 39(2): $464-482$.

Bello SM (2012). Impact of Ethical Leadership on Employee Job Performance. International Journal of Business and Social Science, 3(11): 228 - 236.

Brown ME, Trevino LK, Harrison DA (2005). Ethical Leadership: A Social Learning Perspective for Construct Development and Testing. Organizational Behaviour and Human Decision Processes, 97:117 - 134.

Buchanan B (1974). Building organizational commitment: The socialization of managers in work organizations. Administrative Science Quarterly, December 1, 1: 533-546.

Büschgens T, Bausch A, Balkin DB (2013). Organizing for Radical Innovation. A MultiLevel Behavioural Approach. The Journal of High Technology Management Research, 24(2): $138-152$.

Caldwell C, Hayes LA, Long DT (2010). Leadership Trustworthiness and Ethical Stewardship. Journal of Business Ethics, 96: 497 - 512.

Caldwell DF, Chatman JA, O'Reilly CA (1990). Building Organizational Commitment: A Multifirm Study. Journal of Occupational Psychology, 63: 245 - 261.

Cheah CS, Chong VSW, Yeo SF, Pee KW (2016). An Empirical Study on Factors Affecting Organizational Commitment Among Generation X. Procedia-Social and Behvaioural Sciences, 219 (2016): 167 - 174.

Freeman RE, Stewart L (2006). Developing Ethical Leadership, A Bridge Paper of Business Roundtable Institute for Corporate Ethics, www.corporate-ethics.org

Heilman S, Kennedy-Phillips L (2011). Making Assessment Easier with the Organizational Effectiveness Model Describe a Comprehensive. Step by Step, mixed - methods Assessment Model. Published Online by American College Personnel Assocication and Willey Periodicals, Inc. 15(6): 29-32.

Herrbach O, Mignonac K, Vandenberghe C, Negrimi A (2009). Perceived HRM Practices, Organizational Commitment and Voluntary Early Retirement among Later-Career Managers. Human Resource Management, 48(6): 895 - 915. 
Ismail IB, David YB (2014). Influence of Ethical Leadership towards Organizational Commitment in Schools. International Journal of Scientific and Research Publications, 4(9): $1-6$.

Kaiser RB, Hogan R, Graig SB (2008). Leadership and the fate of Organizations. American Psychologist, 63(2): 96 - 110.

Kelman HC (1958). Compliance, identification and internalization, three processes of attitude change. Journal of Conflict Resolution, 2: 51-60.

Khuong MN, Nhu NVQ (2015). The Effects of Ethical Leadership and Organizational Culture towards Employees' Socialibility and Commitment: A Study of Tourism Sector in Ho Chi Minh City, Vietnam. Journal of Advanced Management Science, 3(4): $329-336$

Kim WG, Brymer RA (2011). The Effects of Ethical Leadership on Manager Job Satisfaction, Commitment, Behavioural Outcomes and Firm Performance. International Journal of Hospitality Management, 30:1020 - 1026.

Liu H, Ke W, Wei KK, Gu J, Chen H (2010). The Role of Institutional Pressures and Organizational Culture in the Firm's Intention to adopt Internet-enabled Supply Chain Management Systems. Journal of Operations Management, 28(5): 372 - 384.

Lukas BA, Whitwell GJ, Heide JB (2013). Why do Customers get more than they need? How Organizational Culture Shapes Product Capability Decisions. Journal of Marketing, 77(1): $1-12$.

Lussier RN, Achua, (2004). Leadership: Theory Application and Skill Development, South-Western Publishing. Egan, MN.

Mahadeen B, Al-Dmour RH, Obeidat BY, Tarhini A (2016). Examining the Effect of the Organization's Internal Control System on Organizational Effectiveness: A Jordanian Empirical Study. International Journal of Business Administration, 7(6):22 - 41.

Marthis RI, Jackson JH (2000). Human resources management. New Jersey, Prentice Hall.

Mentari GB (2015). Analyzing the Effect of Employee Development and Ethical

Leadership on Employee Performance: Case Study of PT. Tirta Investamta Airmadidi. Journal Berkala Ilmiah Etisiensi, 15(4): 291-301.

Meyer JP, Allen NJ (1991). A Three-Component Conceptualization of Organizational Commitment. Human Resource Management Review, 1(1): 61 - 89.

Meyer JP, Stanley DJ, Herscovitch L, Topolnytsky L (2002). Affective Continuance and Normative Commitment to the Organization: A Meta-Analysis of Antecedents, Correlates, and Consequences. Journal Vocational Behaviour, 60(1): 20 - 52.

Mowday RT, Porter LW, Steers RM (1982). Employee - Organizational Linkages: The Psychology of Commitment, Absenteeism and Turnover. Orlando: Academic Press.

Mowday RT, Steers RM, Porter LT (1979). The Measurement of Organizational Commitment. Journal of Vocational Behaviour, 14(2): 224 - 247.

Northouse G (2007). Leadership Theory and Practice, ( $3^{\text {rd }}$ ed.) Thousand Oak, London, New Delhi, Sage Publications Inc.

Nuri TOKT (2013). Teachers Job Satisfaction and Organizational Commitment in Turkey. International Journal of Engineering and Management Sciences, 4(2): 250 - 265.

O'Reilly CA, Chatman JA (1986). Organizational Commitment and Psychological Attachment: The Effects of Compliance, Identification and Internatisation on Prosocial Behaviour. Journal of Applied Psychology, 71:492 - 499.

Obicci PA (2015). Effects of Ethical Leadership on Employee Performance in Uganda. Net Journal of Business Management, 3(1): 1 - 12.

Ramay AM, Ramay MI (2012). Antecedents of Organizational Commitment of Banking Sector Employees in Pakistan. Serbian Journal of Management, 7(1): 89 - 102. 
Schein EH (2010). Organizational Culture and Leadership, (4 ${ }^{\text {th }}$ ed.) San Francisco: Jossey-Bass.

Schneider B, Ehrhart MG and Macey WH (2013), Organizational Climate and Culture. Annual Review of Psychology, 64: $361-388$.

Scullion H, Collings DG, Gunnigle P (2007). International Human Resource Management in the $21^{\text {st }}$ Century: Emerging Themes and Contemporary Debates. Human Resource Management Journal, 17(4): 309 - 319.

Sharma JP, Bajpai N (2010). Organizational Commitment and its Impact on Job Satisfaction of Employees: A Comparative Study in Public and Private Sector in India. International Bulletin of Business Administration, 9(1): 7-19.

Slater SF, Mohr JJ, Sengupta S (2014). Radical Product Innovation Capability: Literature Review, Synthesis and Illustrative Research Propositions. Journal of Product Innovation Management, 31(3): 552 - 566.

Steyrer J, Schiffinger M, Lang R (2005). Organizational Commitment - A Missing Link between Leadership behavior and Organizational Performance? Scandinavian Journal of Management, 24: 364 - 374.

Pande P, Singh S, Pathak (2019). Factor Affecting turnover intentions in the Indian retail industry. International Journal of Human Resources Development and Management, 19(2):166-182.

Tolentino RC (2013). Organizational Commitment and Job Performance of the Academic and Administrative Personnel. International Journal of Information Technology and Business Management, 15(1): 51-59.

Walumbwa FO, Meyer DM, Wang P, Wang H, Workman K, Christensen AH (2011). Linking Ethical Leadership to employee Performance: The Role of Leader-Member Exchange, Self-Efficacy, and Organizational Identification. Organizational Behaviour and Human Decision Processes, 115(2): 204 - 213. 